him are received upon our establishment perfectly pure, and returned to him, roasted, in the same condition.

We are, Sir, yours respectfully,

F. Richards, Manager.

T. Durbridae;?

E. BRADFORD, $\}$ Roasters.

J. DEAN,

P.S.-If required, we shall be happy to make an affidavit to that effect.

London, May 13, 1851.

** The evidence of this correspondence is very strong, and would appear to be conclusive with some persons, that the sample of coffee which our commissioner purchased at the establish. ment of Mr.Abbiss, did not contain "roasted wheat farina." As we attach great importance to the bon $\hat{a}$ fide character of the analytical investigations now in progress, we have not hesitated to place the commissioner who made the examination, and wrote the report, in direct personal communication with Mr. Abbiss, in order that a thorough inquiry may be instituted by persons of acknowledged skill and ability, who have not yet expressed any opinion on the subject. Whatever may be the result of that inquiry, it shall be made known to the public. We will only state that we shall always be infinitely more prompt in affording redress, if at any time our reports should unfortunately contain an error, than in the infliction of an injury. We, however, cannot dismiss this correspondence at this time without referring to a statement contained in the letter of Mr. Abbiss, published at page 530 of the last number of THE LANCET, and those made by the proprietors and managers of the "Patent Desiccating Coffee Company," whose commanications we have just inserted. Mr. Abbiss in his letter, thus writes:- - I always buy the root (chicory) in the raw state, to preclude the possibility of being deceived by a manufactured article."

From this declaration and others contained in the same communication, we inferred that the entire preparation of the chicory and its admixture with coffee took place in the establishment of Mr. Abbiss, but now it turns out that Mr. Relfe, of the "Patent Desiccating Coffee Company, 10, Osbornstreet, Whitechapel, has for a considerable time roasted all Mr. Abbiss' chicory, as well as a moiety of his coffee." This is curious, and it is equally singular to observe, that in not one of the seven communications on the subject is it stated where the said chicory is ground. At all events, it is now proved as an undoubted fact, that although Mr. Abbiss purchased his chicory in the raw state, it is not roasted by him or at his own establishment. How is it that the "Patent Desiccating Coffee Company" are wholesale roasters of chicory? Why not adopt the more appropriate title of Patent Desiccating Coffee and Chicory Company. We again repeat, that we entirely rely on the statement made by Mr. Abbiss, that he has never intentionally or knowingly sent from his establishment coffee containing any other admixture than chicory. Should it be found, as the result of the inquiry now in progress, that the coffee examined by the Commission really did contain roasted wheat farina, or any substance closely resembling it, not one of the public will gain so much by our labours, in this case, as Mr.Abbiss himself; and as the matter stands, with the evidence which we now publish, the good faith of Mr. Abbiss in conducting his establishment is entitled to the fullest admission.-ED. I.

\section{THE ANALYTICAL SANITARY COMMISSION AND MR. BACK.}

To the Editor of The LanceT.

Srr,-In your number of The Lancer of the 10th inst., under the head of the "Analytical Sanitary CommissionChicory and its Adulterations, (Second Report,)" appears the following:-

$$
\text { "14th Sample. }
$$

Purchased-of G. W. Back, 137, Whitechapel-road.

Adulterated-with a very considerable quantity of roasted wheat farina."
Immediately upon my attention being directed to this charge against me, I communicated with Messrs. Barry \& Co., of Type-street, Finsbury, the firm from whom I have for some years past, and do still, purchase my chicory, and who a short time since furnished me with a written assurance and guarantee in the following words, which I take from their letter now in my possession:-

"We deem it right to say, that all chicory sold by us we hold ourselves entirely responsible for its being genuine, and will guarantee all our customers, in the use of it, against any charges that may be made."

At my interview with Messrs. Barry, I handed them THE LANCET, and said-Gentlemen, I now call upon you to vindicate my character, which you know, as well as I feel it to be is that of an honourable and respectable tradesman; and I assure you, (as I likewise do you, Mr. Editor,) that never at any time since I have been in business have $I$ adulterated or mixed anything whatever, in any way, with my chicory; but that I have always sold it precisely in the same state as it comes into my shop; and this $I$ am in a condition to prove in the clearest possible manner, and also that I never had such a thing as wheat farina in my possession.

Messrs. Barry, having the fullest conviction of the truth of my statement, at once declared their desire to render every assistance in their power to refute the charge you have made against me; and $I$ have since received a letter from them, dated the 12th inst., from which $I$ extract the following:-

"With regard to the statement in THE LANCET, that the chicory purchased of you contained a considerable quantity of wheat farina, if you are prepared to show that it was sold by you as received from us, we are willing to see the Editor of The Lancet with you upon the subject, or to render any assistance you may require to refute the charge."

Now, Sir, I can show, to the satisfaction of any jury, that I have always sold chicory precisely in the same state as delivered to me by Messrs. Barry; and as I have the fullest confidence in their integrity, I think it right to add, that the charge made by you, in last week's edition of THE LANCET, cannot be well founded.

I request that, in fairness to me, which $I$ am sure $I$ shall meet at your hands, you will insert this letter in your next publication; but if, in the meantime, you think Messrs. Barry's suggestion of an interview, or any other course, desirable, I shall be only too anxious to render every assistance.

I am, Sir, your obedient servant,

Britannia Tea Warehouse, 137, whitechapel-road, G. W. BACK, May 13, 1851 .

* * The contents of this letter are strongly indicative of the integrity and strict propriety of conduct which Mr. Back has pursued, and far be it from us to impeach, in any way, the accuracy of the statement made by Messrs. Barry. Still it is ovident that allegations which clash so strongly with the report of our commission demand a searching inquiry. The commissioner, therefore, who made the examination, will place himself in immediate communication with $M$ r. BACK and the Messrs. BARRY; and in this case also the result of a further analytical investigation shall be announced in our columns.ED. $\mathbf{L}$.

\section{SMALL.POX AND VACCINATION.} To the Editor of THe LANCET.

Sir,-The debate on small-pox and vaccination at the Royal Medical and Chirurgical Society must for some time to come keep the minds of medical men fixed steadily on those important subjects, and may perhaps crowd your pages with opinions as to the dicta of the various speakers. Should this occur, so as to elicit further explanations from the distinguished authorities who took part in the discussion, you will, I doubt not, think your space well occupied.

The cases of Dr. Webster are those of three brothers, all vaccinated, who nevertheless contracted variola, one of them once, another twice, and the third three times, the last attack being fatal. Dr. Stewart's case is called confluent small-pox after a third vaccination. It seems doubtful, however, from the writer's own description, whether the vesicles (query pustules) were confluent at all-whether, in fact, they were not distinct, though very numerous, and closely packed. One may fairly object, too, to reckon three vaccinations, where it appears that once the operation totally failed, and on another of the three occasions it produced a vesicle obviously irregular. This was evidently a very dangerous case, and little calculated 